\title{
Ortaokullarda Görev Yapan Öğretmenlerin Öğretmen Motivasyonuna ìlişkin Algı ve Görüşleri
}

\author{
Perceptions and Views of Teachers Who Work in Middle Schools Regarding \\ Teacher Motivation
}

\author{
Yrd. Doç. Dr. Soner Doğan - Osman Koçak
}

\section{Öz}

Bu araștırmanın amacı öğretmenlerin motivasyon düzeylerini, ortaokullarda görev yapan branş ögretmenlerinin algilarına ve görüşlerine göre değerlendirmektir. Araştırmada, nicel ve nitel yöntemleri içerisine alan açıklayıcı (explanatory) desen kullanılmıştır. Araştırmanin nicel bölümü ilişkisel tarama modelinde desenlenmiştir. Veriler, Sivas ilinde görev yapan 211 öğretmenden, "Öğretmenlere Yönelik Motivasyon Ölçeği" araciliğtyla toplanmıştır. Araştırmanın nitel bölümü ise durum çalışması desenine uygun olarak yürütülmüştür. Veriler, nicel bölümde kullanılan ölçeğin içeriğine uygun olarak hazırlanan 3 adet açık uçlu sorudan oluşan yarı yapılandırılmış görüş̧me formu aracıliğıyla Sivas ilinde görev yapan 10 ögretmenden yüz yüze yapılan görüş̧melerle elde edilmiştir. Araştırmanın nicel bulguları öğretmenlerin motivasyon düzeylerini yüksek düzeyde olumlu algıladıklarmi; nitel bulgular ise ögretmenlerin motivasyon düzeylerini genel olarak yeterli bulmadıklarını göstermektedir. Bu bağlamda nitel bulguların nicel bulguları desteklemediği söylenebilir.

Anahtar Kelimeler: Motivasyon, Öğretmen Motivasyonu, Branş Öğretmenleri

\begin{abstract}
The aim of this study is to evaluate the level of teacher motivation according to the perceptions and views of the branch teachers who work in secondary schools. In this research, explanatory pattern involving quantitative and qualitative methods is used. Quantitative part of the research has been designed in relational survey model. The data was collected through "Motivation Scale for Teachers" from 211 teachers working in the Province of Sivas. Qualitative part of the research, however, was conducted in accordance with case study pattern. The data was obtained through semi-structured interview form consisting of three open-ended questions prepared according to the content of the scale used in the quantitative part from 10 teachers working in the Province of Sivas in face-to-face interviews. Quantitative findings of the study show that teachers perceive their level of motivation highly positive, while qualitative findings show that they don't generally find their level of motivation enough. In this context, it can be said that the qualitative findings do not support the quantitative ones.
\end{abstract}

Keywords: Motivation, Teacher Motivation, Branch Teachers

Yrd. Doç. Dr. Soner Doğan, Cumhuriyet Üniversitesi Eğitim Fakültesi, snr312@gmail.com Osman Koçak, Milli Eğitim Bakanlığı, kocak.2012@hotmail.com 


\section{Giriş}

Motivasyon kelimesi Latince' de "harekete geçirmek" anlamina gelen "movere" kelimesinden İngilizce 'ye girmiştir (Lunenburg ve Ornstein, 1996). İngilizceden de dilimize giren "motivasyon" kelimesinin ingilizcesi "motivation" kelimesidir (Gündüz, 2009). İlgili alanyazın incelendiğinde motivasyon kavramının çok çeşitli şekillerde tanımlandığı görülmektedir. Buna göre motivasyon, canlıyı (organizmayı) belli bir amaç için harekete geçiren etki, güçtür (Gürgen, 1997; Şişman, 2003). Benzer şekilde motivasyon, çalışanların bazı bireysel ihtiyaçlarını tatmin ederek, iş başarısını arttırmak ve daha üst düzeyde çalışmak için bir isteklilik ortaya çıkarma biçiminde tanımlanabilir (Harzing ve Ruysseveldt, 1995, s. 138). Diğer bir tanımda ise motivasyon, insanların beklenen ve istenen yönde hareket etmelerini teşvik eden güdü veya insanın amaçlarına ulaşabilmesi için insana yardımcı olan, insanın performansını arttıran ödüldür (Karagöz, 2010; Sergiovanni ve Starratt, 1993; Aydın, 2011).

Bir örgütte çalışanların motivasyonları yüksek olduğunda moralleri ve iş tatminleri de yüksek olur. Bunun sonucunda da iş performansları yüksek olur (Gürgen, 1997). Bu nedenle örgütsel amaçlara ulaşabilmek için çalışanların gereksinimlerinin çok iyi bilinmesi ve karșilanması gerekmektedir (Tuna ve Türk, 2006; Gürüz ve Yaylacı, 2007). Calıșanların gereksinimlerinin karşılanmasında ise yöneticilere önemli görevler düşmektedir. Yönetici, bir örgütün amaçlarını gerçekleştirmek amacıyla, örgütün mevcut yapısını ve prosedürü kullanan kişidir (Aydın, 2010). Okul örgütünün yöneticisi ise, okulun amaçlarını yerine getirebilmek için okuldaki tüm işgörenleri örgütleyen, onlara emirler veren, okuldaki çalışmaları yönlendirip koordine eden ve denetleyen kişidir. Okul yöneticisi, Milli Eğitim Bakanlığı’nın eğitim politikaları ve amaçları doğrultusunda okulunu en iyi şekilde yönetmeyi amaçlar (Gürsel, 1997). Okullarını en iyi şekilde yönetmek için çaba sarf eden okul yöneticileri, bir taraftan okullarında hedeflenen başarıya ulaşmak ve örgütsel amaçları gerçekleştirmek için çalışmalı, bir taraftan da öğretmenlerin kişisel beklentilerini karşılamaya ve öğretmenlerinin motive olmalarını sağlamaya çalışmalıdır (Yılmaz ve Ceylan, 2011). Çünkü eğitim örgütlerinde liderlerin ve yöneticilerin kalitesi, öğretmen motivasyonu ve eğitimin kalitesine göre değerlendirilmektedir (Haris, 2004).
Okulların en önemli çalışanı konumunda olan öğretmenlerin ekonomik, sosyal-psikolojik ve örgütsel-yönetsel gereksinimlerinin karşılanması, onların motivasyonunu doğrudan etkiler (Baygül ve İnam, 2006). Çünkü öğretmen, eğitim-öğretimin yapılmasında, eğitimin amaçlarının gerçekleştirilmesinde, öğrencilerin motivasyonunun sağlanmasında, eğitimde diğer önemli unsurlar olan yönetici, veli, öğrenci arasındaki koordinasyonun ve eşgüdümün sağlamasında en öncelikli unsurdur. Bu açıdan bakıldığında, eğitimde hedeflenen başarıyı yakalamak ve hedeflenen amaçlara ulaşabilmenin en önemli şartı öğretmenlerin performansıdır. Öğretmenlerin performansını doğrudan etkileyen en önemli faktörler ise işlerinde tatmin olmaları ve işlerine motive olmalarıdır (Karadeniz ve Yavuz, 2009). Öğretmenlerin başarısı ile motivasyonları arasında doğru bir orantı olduğundan, motivasyon düzeyi yüksek öğretmenler daha başarılı olacaktır (Yazıcı, 2009). Bu nedenle okul yöneticileri, okullarında istenilen düzeyde başarıyı yakalamak ve örgütsel amaçlara ulaşabilmek için öğretmenlerin kişisel beklentilerini yerine getirmeye gayret göstermeli, onların motive olmalarını sağlayacak motivasyon araçlarını kullanmalı ve öğretmenlerin motivasyonlarını arttırıcı nitelikte bir okul ortamı oluşturmaya çalışmalıdır (Yılmaz ve Ceylan, 2011).

İlgili alan yazın incelendiğinde eğitim kurumlarında öğretmen motivasyonu ile ilgili çalışmalara rastlanmaktadır. Neves ve Lens (2005), Wahab vd. (2013) liderlik ve öğretmen motivasyonu; Liu ve Onwuegbuzie (2011), Ololube (2006), Griffin (2010) iş doyumu ve öğretmen motivasyonu; Ahmad (2011), Kaur ve Kaur (2013) öğretmenlerin yeterlilik inançları ve öğretmen motivasyonu; Neves ve Lens (2005), Morcom ve MacCallum (2009), Jesus ve Abreu (1994), Vrieling vd. (2012), Papi ve Abdollahzadeh (2012), Sakui ve Cowie (2012), Ciani vd. (2010) öğrenci başarısı ve öğretmen motivasyonu; Özan vd. (2012) demokratik tutum ve davranışlar ile öğretmen motivasyonu; Özdoğru ve Aydın (2012) karara katılım ve öğretmen motivasyonu; Güneş (2007), Özgan ve Aslan (2008), Torbacıoğlu (2007) Bektaş (2010), Sabancı (1994) iletişim ve öğretmen motivasyonu konularında çalışmalar yapmışlardır. Görüldüğü üzere öğretmen motivasyonu farklı konular ile ilişkilendirilerek genel olarak nicel yöntemlerle incelenmiştir. Bu bağlamda alan yazında ortaokullarda görev yapan branş öğretmenlerinin motivasyon algılarının hem nitel hem de nicel 
yöntem ile birlikte değerlendirildiği karma yönteme dayalı bir çalışmaya rastlanmamıştır. Araştırmaya getirilen bu farklı bakış açısı ile öğretmen motivasyonu hem "Öğretmenlere Yönelik Motivasyon Ölçeği" aracılığıyla öğretmen algıları düzeyinde hem de açık uçlu sorularla öğretmen görüşlerine dayalı olarak değerlendirilmiş, nicel ve nitel bulgular karşılaştırılarak konu hakkında daha güvenilir sonuçlara ulaşılmıştır. Araştırma bu bakımdan öğretmen motivasyonu konusunda yapılan diğer araştırmalardan farklılaşmakta alan yazına yeni bir bakış açısı kazandırmasıyla önem arz etmektedir. Bu kapsamda araştırmada aşağıdaki sorulara yanıt aranmıştır:

1. Ortaokullarda görev yapan öğretmenlerin, öğretmen motivasyonuna ilişkin algıları ne düzeydedir?

2. Ortaokullarda görev yapan öğretmenlerin, öğretmen motivasyonuna ilişkin algıları öğretmenlerin cinsiyetlerine göre farklılık göstermekte midir?

3. Ortaokullarda görev yapan öğretmenlerin, öğretmen motivasyonuna ilişkin algıları öğretmenlerin branşlarına göre farklılık göstermekte midir?

4. Ortaokullarda görev yapan öğretmenlerin, öğretmen motivasyonuna ilişkin görüşleri nelerdir?

\section{Yöntem}

\section{Araştırma Modeli}

Araştırmada nicel ve nitel yöntemler birlikte kullanılmıştır. Nicel ve nitel araştırma tekniklerinin birlikte kullanılmasında üç desen işe koşulabilir. Bunlar zenginleştirilmiş (triangulation) desen, açılkayıcı (explanatory) desen ve keşfedici (exploratory) desen olarak ele alınabilir. Zenginleştirilmiş desende nicel ve nitel veriler birlikte toplanır, bu verilerin birbirlerini destekleyip desteklemediğine bakılır. Açıklayıcı desende ise önce nicel veriler toplanır, sonra bu verileri yorumlamak için nitel araştırmaya gidilir. Keşfedici desende önce nitel veriler toplanır, sonra bunlara dayanarak nicel verilerin toplanmasına gidilir (Fraenkel ve Wallen, 2006; Akt., Sönmez ve Ceylanpınar, 2011).

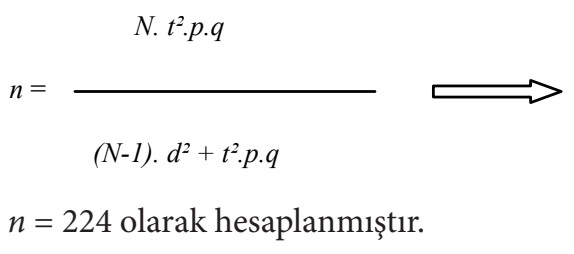

Bu bağlamda değerlendirildiğinde bu araştırma açıklayıcı desen kapsamında yapılandırılmıştır. İki araştırma yönteminin birlikte kullanılmasıla konu ile ilgili daha kapsamlı ve derinlemesine bilgi edinilmesi, araştırma sonucunda daha güvenilir ve sağlıklı çıkarımlarda bulunulması amaçlanmaktadır.

Nicel Araştırma Modeli: Araştırmanın nicel bölümü tarama modeline dayalı betimsel bir çalışmadır. Karasar’a (2011) göre tarama modeli, geçmişte ya da halen var olan bir durumu var olduğu şekliyle betimlemeyi amaçlayan araştırma yaklaşımıdır. Araştırmaya konu olan olay, birey ya da nesne, kendi koşulları içinde ve olduğu gibi tanımlanmaya çalışılır. Onları herhangi bir şekilde değiştirme, etkileme çabası gösterilmez. Bu kapsamda araştırmada ortaokullarda görev yapan branş öğretmenlerin algılarına göre öğretmen motivasyonu incelenmiştir.

Nitel Araştırma Modeli: Çalışmanın nitel bölümünde durum deseni kullanılmıştır. Nitel durum çalışmasının amacı belirli bir duruma ilişkin sonuçlar ortaya koymak iken en temel özelliği bir ya da birkaç durumun katılımcı gözlemleri, derinlemesine görüşmeler yoluyla doküman toplama ile elde edilen ve analiz edilen verilerin derinliğine ve boylamsal olarak incelenmesini içerir (Yıldırım ve Şimşek, 2011). Bu kapsamda katılımcıların, öğretmen motivasyonuna ilişkin görüşleri açık uçlu sorular aracılığıyla irdelenmiştir.

\section{Çalışma Grubu}

Nicel Yöntemde Kullanılan Çalışma Grubu: Araştırmanın nicel bölümünde evreni 2012-2013 eğitim-öğretim yilında Sivas il merkezinde bulunan ortaokullarda görev yapan Türkçe, Matematik, Fen ve Teknoloji, Sosyal Bilgiler ve İngilizce branşlarında toplam 531 öğretmen oluşturmaktadır. Araştırma sonucundan daha sağlıklı sonuçlar elde edebilmek amacıyla öğretmen sayısı birbirine en yakın olan söz konusu beş branş araştırmanın evreni olarak belirlenmiştir.

Araştırmanın örneklemi ise, olasılık temelli örnekleme yöntemlerinden olan seçkisiz örnekleme yöntemiyle belirlenmiştir. Seçkisiz örnekleme yöntemi, örneklemin istatistiksel hesaplamalarla evreni temsil edebilecek büyüklüğe sahip ve tamamen rastgele se-

531.(1.96) $)^{2} .(0.5) \cdot(0.5)$

$n=$

$530 .(0.05)+(1.96)^{2} .(0.5) .(05)$ 
çilmesidir (Şimşek ve Yıldırım, 2006). Araştırma örnekleminin hesaplanmasında aşağıdaki formül kullanılmıştır (Yazıcıoğlu ve Erdoğan, 2004).

Yapılan hesaplamalara göre araştırmanın örneklemini Sivas Merkez ilçedeki ortaokullarda Türkçe, Matematik, Fen ve Teknoloji, Sosyal Bilgiler ve İngilizce branşlarında görev yapan 224 branş öğretmeni oluşturmak- tadır. Araştırmanın uygulama kısmında kullanılan istatistiksel metotların varsayımlarından olan normallik varsayımının sağlanması için normal dağılımın dışına çıkan uç değerlere sahip 13 öğretmene ait veriler çalışmadan çıkarılmış ve söz konusu istatistiksel analizlerde 211 ögretmene ait veriler kullanılmıştır. Araştırmanın örneklemini oluşturan öğretmenlere ilişkin kişisel bilgilere Tablo 1'de yer verilmiştir.

Tablo 1. Araştırmaya Katılan Öğretmenlere illişkin Kişisel Bilgiler

\begin{tabular}{llll}
\hline Değişkenler & Kategoriler & f & $\mathbf{( \% )}$ \\
\hline \multirow{2}{*}{ Cinsiyet } & Erkek & 106 & 50.2 \\
& Kadın & 105 & 49.8 \\
\hline \multirow{4}{*}{ Branş } & Türkçe & 57 & 27 \\
& Matematik & 45 & 21.3 \\
& Fen ve Teknoloji & 39 & 18.5 \\
& Sosyal Bilgiler & 30 & 14.2 \\
\hline TOPLAM & İngilizce & 40 & 19 \\
\hline
\end{tabular}

Tablo 1'de görüldüğü üzere çalıșmaya katılan öğretmenler, cinsiyete göre değerlendirildiğinde \%50,2'sinin erkek, \%49,8'inin kadın olduğu; branşlarına göre değerlendirildiğinde \%27'sinin Türkçe, \%21,3'ünün Matematik, \%18,5'inin Fen ve Teknoloji, \% 14.2'sinin Sosyal Bilgiler ve \%19.0'unun da İngilizce branşlarında olduğu saptanmıştır.

Nitel Yöntemde Kullanılan Çalı̧̧ma Grubu: Araştırmanın nitel bölümünde amaçlı örnekleme yöntemlerinden maksimum çeşitlilik örnekleme yöntemi kullanılmıştır. Maksimum çeşitlilik örneklemesi; göreli olarak küçük bir örneklem oluşturarak bu örnek- lemde çalıșlan probleme taraf olabilecek bireylerin çeşitliliğini maksimum derecede yansıtmaktır (Y1ld1rım ve Şimşek, 2011, s.113). Bu bağlamda araştırmada, öğretmen motivasyonuna taraf olan öğretmenler örnekleme alınmıştır. Buna göre örnekleme alınacak katılımcılar belirlenirken branş, görev yeri ve cinsiyet kriterleri dikkate alınmıștır. Tablo 2'de görüldüğü üzere 5 branştan, her bir branştan 3 öğretmen olmak üzere; cinsiyet dağılımına göre 7 erkek 8 kadın öğretmen olmak üzere; yerleşim yerlerinin dağılımında ise 8'i araştırma yapılan ilin merkezinde sosyo-ekonomik ve kültürel düzeyi yüksek olan bölgelerde görev yapan, 7'si araştırma yapılan ilin merkezinde sosyo-

Tablo 2. Öğretmenlerin Branş, Cinsiyet ve Yerleşim Yerine Göre Özellikleri

\begin{tabular}{|c|c|c|c|}
\hline & Cinsiyet & Branş & Yerleşim yeri \\
\hline Katılımc1 1 & Erkek & Türkçe & Il merkezi \\
\hline Katılımc1 2 & Kadın & İngilizce & İl merkezi \\
\hline Katılımc1 3 & Erkek & Sosyal Bilgiler & İl merkezi \\
\hline Katılımc1 4 & Kadın & Fen ve Teknoloji & İl merkezi \\
\hline Katılımeı 5 & Kadın & Türkçe & İl merkezi \\
\hline Katılımeı 6 & Erkek & İngilizce & İl merkezi \\
\hline Katılımcı 7 & Kadın & Fen ve Teknoloji & İl merkezi \\
\hline Katılıme1 8 & Erkek & İngilizce & İl merkezi \\
\hline Katılımc1 9 & Kadın & Türkçe & İl merkezi \\
\hline Kat1lıme1 10 & Erkek & Fen ve Teknoloji & İl merkezi \\
\hline Katılımeı 11 & Kadın & Matematik & İl merkezi \\
\hline Kat1lımeı 12 & Kadın & Sosyal Bilgiler & İl merkezi \\
\hline Kat1lımc1 13 & Kadın & Matematik & İl merkezi \\
\hline Katılımcı 14 & Erkek & Matematik & İl merkezi \\
\hline Kat1lımci 15 & Erkek & Sosyal Bilgiler & İl merkezi \\
\hline
\end{tabular}


ekonomik ve kültürel düzeyi düşük olan bölgelerden olmak üzere toplam 15 öğretmen örnekleme alınmıştır. Aynı zamanda katılımcılar belirlenirken görüşme yapmayı kabul etme ve katılmaya istekli olma durumu da göz önünde bulundurulmuştur. Katılımcı ögretmenlerle ilgili kişisel bilgiler Tablo 2'de ayrıntılı olarak sunulmuştur:

\section{Veri Toplama Araçları}

Nicel Veri Toplama Araçları: Araştırmanın nicel bölümünde veri toplama aracı olarak kullanılan anketin ilk bölümünde ortaokullarda görev yapan branş öğretmenlerinin demografik özelliklerini incelemek amacıyla Kişisel Bilgi Formu; ikinci bölümde, ortaokullarda görev yapan branş öğretmenlerinin motivasyonunu ölçmek amacıyla Bektaş (2010) tarafından geliştirilen "Öğretmenlere Yönelik Motivasyon Ölçeği” kullanılmıştır. Araştırmacı, öğretmenlere yönelik motivasyon ölçeğinin geliştirilmesi sürecinde, yöneticilere yönelik belirlediği motivasyon maddelerini uzman görüşüne sunmuş ve uzmanların görüşü doğrultusunda belirlenen 20 tane motivasyon maddesinin araştırmada kullanılmasına karar verilmiş- tir. Oluşturulan anketin alt faktörlerini belirlemek, geçerlilik ve güvenilirlik çalışmalarını yapmak için gereken istatistik teknikler uygulanmıştır. Verilerin faktör analizi için uygunluğu, Kaiser-Meyer-Olkin $(K M O)$ katsayısı ve Bartlett Sphericity testi ile incelenmiştir. KMO'nun 0.50 ' dan yüksek çıkması ve Bartlett Sphericity testinin anlamlı çıkması verilerin faktör analizi için uygunluğunu gösterir. Bu ölçek için yapılan faktör analizi sonuçlarında KMO 0.50' den büyük $(K M O=0.892)$ ve Bartlett testinin sonucu anlamlı ( $p=0.000)$ çıkmıştır (Bektaş, 2010).

Öğretmenlere uygulanan bu ölçeğe uygulanan faktör analizi sonucunda ise ölçeğin dört faktörden oluştuğu görülmektedir. Bu dört faktörün ölçeğe ilişkin açıkladığı varyans $\% 71$ olarak belirlenmiştir. Maddelerle ilgili olarak tanımlanan dört faktörün ortak varyansları ise 0.53 ile 0.82 arasında değişmektedir. Buna göre analizde önemli faktör olarak ortaya çıkan dört faktörün birlikte, maddelerdeki toplam varyansın ve ölçeğe ilişkin varyansın çoğunluğunu açıklamakta olduğu belirlenmiştir (Bektaş, 2010). Yirmi maddelik motivasyon ölçeğinin faktörleri maddelerine göre Tablo 3'de verilmiştir:

\begin{tabular}{lll}
\multicolumn{2}{l}{ Tablo 3. Öğretmenlere Yönelik Motivasyon Ölçeği ve Boyutları } \\
\hline Boyut & Öğretmenlerin Motivasyonu & İlgili Sorular \\
\hline 1 & Yönetici ile Çalışma & $3-4-5-6-10-14-15$ \\
2 & Yönetici Saygısı & $7-8-9-17-18$ \\
3 & Yönetici-Bireysel İhtiyaç İlişkisi & $12-16-19-20$ \\
4 & Yönetici Tutum Davranışları & $1-2-11-13$ \\
\hline
\end{tabular}

Tablo 3'de görüldüğgü üzere ölçek "yönetici ile çalışma", "yönetici saygısı", "yönetici-bireysel ihtiyaç ilişkisi" ve "yönetici tutum davranışları" adlı dört boyuttan oluşmaktadır. Her bir faktör için elde edilen Cronbach Alpha güvenirlik katsayıları 0.85 ve üstündedir. Ölçeğin genel düzeyde Cronbach Alpha güvenirlik katsayısı ise $\alpha=0.94$ olarak hesaplanmıştır (Bektaş, 2010). Ölçekte, "yöneticimin tutum ve davranışları benim güven içinde çalışmama olanak sağlar; Yöneticimin demokratik tutum göstermesi beni mutlu eder; Yöneticimin okulda yapılan çalışmalar hakkında bilgi vermesi beni memnun eder; Yöneticim, öğretmenlerin alınan kararlara katılmasını sağlar" gibi maddeler yer almaktadır.
Nitel Veri Toplama Araçları: Araştırma kapsamında katılımcılara yöneltilecek açı uçlu sorular öncelikle araştırmanın çalışma grubunda iki öğretmene yöneltilmiş, elde edilen sonuçlara göre soruların açı ve anlaşılır olduğu görülmüştür. Ayrıca sorular nitel araştırmalar konusunda uzman bir öğretim üyesi tarafından incelemeye tabi tutulmuş ve son olarak bir Türkçe öğretmeni tarafından gözden geçirilmiştir.

Veri toplama sürecinde katılımcılara açık uçlu sorular yöneltilerek araştırma sürecinde beklenmeyen veya planlanmayan cevapların alınması sağlanmış, böylece konu hakkında daha geniş ve ayrıntılı bilgiye sahip olunmuştur (Büyüköztürk vd., s.127). Sorular 
katılımcıların belirli bir anda belirli bir konuya yönelik ne düşündüğünü ya da ne duyduğunu saptamaya yönelik tutum, inanç ve kanı sorularıdır (Balc1, 2010). Araştırmanın soruları hazırlanırken Öğretmenlere Yönelik Motivasyon Ölçeğinin alt boyutları dikkate alınmıştır. Buna göre araştırmada katılımcılara yöneltilen sorular şunlardır: $i$. Yöneticinizin size ve yaptığınız çalışmalara saygı gösterip göstermemesi sizin motivasyon düzeyinizi nasıl etkilemektedir? (yönetici saygısı boyutu) ii Yöneticinizin bireysel ihtiyaçlarınıza karşı duyarlı olup olmaması motivasyon düzeyinizi nasıl etkilemektedir? (yönetici-bireysel ihtiyaç ilişkisi boyutu) iii. Yöneticinizin yönetime ilişkin tutum ve davranışlarının motivasyon düzeyinizi nasıl etkilemektedir? (yönetici tutum ve davranışları boyutu). "Yönetici ile çalışma" boyutu diğer boyutların içeriğinde değerlendirilerek bu boyut için ayrı bir soru hazırlanmamıştır. Araştırma kapsamında elde edilen sorular 15 katılımcıya yöneltilmiştir. Araştırmaya ilişkin veriler Ocak 2014- Şubat 2014 tarihleri arasında belirlenen katılımcılarla yapılan konu odaklı görüşme yöntemiyle toplanmıştır. Konu odaklı görüşmeler kişilerin yaşamlarından ziyade bir program, konu ya da süreç üzerine odaklanmış görüşmelerdir. Görüşmeler hakkında katılımcılara bilgi verilmiş daha sonra katılımcılardan randevu alınmış ve tam randevu saatinde okullara gidilerek sessiz bir ortamda görüşmeler gerçekleştirilmiştir. Görüşmelerde katılımcıların onayı ile ses kayıt cihazı kullanılarak 340 dakikalık ses kaydı elde edilmiştir.

\section{Verilerin Analizi}

Nicel Verilerin Analizi: Öğretmenlerin demografik özelliklerine ilişkin yapılan analizlerde frekans ve yüzde değerlerine; öğretmen motivasyonuna ilişkin olarak, seçeneklere göre kodlanan puan aralığ 1 dağılımı hesaplanırken, aritmetik ortalama ve standart sapma değerlerine yer verilmiştir. Araştırmanın alt problemleri çözümlenirken ikili karşılaştırmalarda t-testi, üç ve daha fazla boyutu olan karşılaştırmalarda tek yönlü varyans analizi (ANOVA) kullanılmıştır.

Nitel Verilerin Analizi: Araştırma sürecinde katılımcılarla yüz yüze gerçekleştirilen tüm görüşmeler, ses kayıt cihazıyla, katılımcıların onayı alınarak kaydedilmiştir. Bu kapsamda katılımcılar ile 340 dakikalık görüşme yapılmıştır. Görüşmelerden sonra kaydedilen veriler ham veri olarak Microsoft Word yazı işleme programiyla metne dönüştürülmüştür. Veriler kodlanmadan önce iki araştırmacı tarafından verilerin dökümü olan transkriptler satır satır okunmuştur. Görüşme verilerinin yorumlanması sürecinde betimsel analiz, içerik analizi ve sürekli karşılaştırma tekniği kullanılmıştır. İçerik analizi, yazılı ve sözlü materyallerin sistemli bir analizidir. İçerik analizi, bir söylemi anlamada ve yorumlamada, öznel etkenlerden kurtularak toplanan verileri açıklayabilecek kavramlara ve ilişkilere ulaşma amacı taşımaktadır (Bilgin, 2006; Yıldırım ve Şimşek, 2011). Betimsel analizde toplanan veriler üzerinde hiçbir işlem yapmadan onların okuyucuya olduğu gibi sunulması savunulur. Burada araştırmacının yorumlayarak verileri olduğundan farklı bir biçimde göstermesi engellenmektedir. Verilerin olduğu gibi, açık, anlaşılır şekilde sunulması tarafsızlığın sağlanması için de gerekli olabilir (Sönmez ve Alacapınar, 2011, s.158). Sürekli karşılaştırma analizinde ise veriler önceden düzenlenmiş kategorilere göre analiz edilmez. Önce veriler elde edilir, sonra onlar kategorize edilir. Bu araştırma yönteminde verilerin sürekli karşılaştırılması söz konusudur. Benzerlik, benzer anlam içeren özellikler kalmadığı zaman yeni kategoriler oluşturulmalı ve veriler o kategorilere yerleştirilmelidir (Strauss ve Corbin, 1990; Strauss ve Corbin, 1998: Akt. Sönmez ve Ceylanpinar, 2011). Bu amaçla veriler dört aşamada analiz edilmiştir: (1) verilerin kodlanması, (2) temaların bulunmas1, (3) kodların ve temaların düzenlenmesi, (4) bulguların tanımlanması ve yorumlanması. Katılımcilara (K1, K2, K3.......K15) şeklinde rumuzlar verilmiştir.

Nitel Araştırmada Geçerlik ve Güvenirlik: Nitel araştırma yaklaşımının benimsendiği bu araştırmada geçerlik ve güvenirlik kavramları yerine inandırıcılık, aktarılabilirlik, tutarlılık ve teyit edilebilirlik kavramlarının kullanılması daha doğru bir yaklaşım olacaktır. Geçerlik ve güvenirlik kavramları nicel araştırmalara özgü kavramlar niteliğinde olup, nitel araştırmaların temel ilkeleri ve temel paradigması ile çelişmektedir (Mills, 2003, s.78).

Bu kapsamda araştırmada inandırıcıllğı sağlamak için öncelikle araştırmanın uygulama sürecinde tüm görüşmeler ses kayıt cihazıyla kayıt altına alınmıştır. Araştırmacı, araştırmanın tüm aşamalarında mümkün olduğunca objektif olmaya dikkat etmiştir. Aktarılabilirlik konusunda araştırmacıların okuyuculara, uygulama ve içerikteki benzerliklere karar vermesi için yeterli detayları vermesi gerekmektedir. Bu ne- 
denle çalışmanın yöntem bölümünde; araştırmanın yapıldığı yer, zaman ve içerik ile ilgili açıklayıcı bir şekilde bilgi verilmiş̧ir. Araştırmanın tutarlılığını artırmak için çalışmada elde edilen bulguların tamamı yorum ve genelleme yapılmadan doğrudan okuyucuya sunulmuştur. Ayrıca araştırma sürecinde elde edilen tüm veriler, araştırmacının kendisi dışında, başka bir araştırmacı tarafından değerlendirip, ayrı ayrı kodlanmış ve tüm kodlamalar arasında genel anlamda görüş birliği sağlanmıştır. İki araştırmacının birbirinden bağımsız olarak kullandıkları kodların tutarlığı "Görüş Birliği” ya da "Görüş Ayrıllğ̆ı" şeklinde işaretlemeler yapılarak belirlenmiştir. Araştırmanın teyit edilebilirliğini sağlamak için, verilerin nasıl toplandığı, verilerin nasıl kaydedildiği ayrıntılı bir şekilde anlatılmıştır.

\section{Bulgular}

Nicel Araştırma Yönteminden Elde Edilen Bulgular $\mathrm{Bu}$ bölümde, ilk olarak öğretmenlerin motivasyon algılarına ilişkin olarak aritmetik ortalama, standart sapma ve seçeneklere göre kodlanan puan aralığ 1 (SKPA) değerlerine yer verilmiştir. Daha sonra ortaokullarda görev yapan branş öğretmenlerinin motivasyonları öğretmenlerin cinsiyet ve branş değişkenlerine göre incelenmiştir. İnceleme sonucuna göre elde edilen bulgulara ve bulgular doğrultusunda geliştirilen yorumlara yer verilmiştir. Ortaokullarda görev yapan branş öğretmenlerinin motivasyonlarının cinsiyet değişkenine göre farklılık gösterip göstermediği $\mathrm{t}$ testi ile, branş değişkenine göre farklılık gösterip göstermediği ise Tek Yönlü Varyans Analizi ile test edilmiştir.

Tablo 4. Öğretmenlerin Motivasyon Düzeylerine Ilişskin Algılarının Genel Dağılımı

\begin{tabular}{lllll}
\hline & $\mathbf{n}$ & $\overline{\mathcal{X}}$ & ss & Seçeneklere Göre Kodlanan Puan Aralığı (SKPA) \\
\hline & & & & \\
Yöneticiyle Çalışma & 211 & 4,39 &, 55 & Tamamen Katıllyorum \\
Yönetici Saygısı & 211 & 4,46 &, 51 & Tamamen Katılıyorum \\
Yönetici-Bireysel İhtiyaç İlişkisi & 211 & 4,01 &, 72 & Katılıyorum \\
Yönetici Tutum ve Davranışları & 211 & 4,41 &, 55 & Tamamen Katıllyorum \\
Motivasyon (toplam) & 211 & 4,31 &, 58 & Tamamen Katılıyorum \\
\hline
\end{tabular}

Öğretmenlerin motivasyon düzeylerine ilişkin algılarının genel dağılımı Tablo 4'de sunulmuştur.

Tablo 4'de motivasyon düzeyi ve alt boyutları, seçeneklere göre kodlanan puan aralığ alınarak değerlendirildiğginde, örneklem grubundaki öğretmenlerin algılarına göre yöneticiyle çalışma $(\bar{X}$ $=4,39)$, yönetici saygısı $(\bar{X}=4,46)$, yönetici tutum ve davranışları $(\overline{\mathrm{X}}=4,41)$ boyutlarının "tamamen kat1lıyorum" düzeyinde; yönetici-bireysel ihtiyaç ilişkisi boyutunda ( $\overline{\mathrm{X}}=4,01)$ "katılıyorum" düzeyinde olduğu görülmektedir. Motivasyon düzeyi toplamda ise $(\overline{\mathrm{X}}=4,31)$ "tamamen katıliyorum" şeklinde algılanmıştır. Öğretmenlerin tüm boyutlarda yönetici kaynaklı nedenlere bağlı olarak motivasyon düzeylerini "tamamen katılıyorum" ve "katılıyorum" düzeyinde olumlu algılamaları öğretmenlerin kendi motivasyon düzeylerinin yeterliliğini sağlama noktasında, ilgili yönetici davranışlarını yeterli düzeyde algıladıkları şeklinde açıklanabilir.
Öğretmenlerin motivasyon düzeylerine ilişkin alg1larının cinsiyet değişkenine göre dağılımı Tablo 5’de sunulmuştur.

Tablo 5’e göre öğretmenlerin yöneticiyle çalışma, yönetici saygısı, yönetici-bireysel ihtiyaç ilişkisi ve yönetici tutum ve davranışları boyutlarına ilişkin motivasyonları cinsiyetlerine göre anlamlı bir farklılık göstermemektedir. Aritmetik ortalama değerlerinin ( $\overline{\mathrm{X}}=3,96$ ile $\overline{\mathrm{X}}=4,49$ ) aralığında değişmesi ve yönetici kaynaklı nedenlere bağlı olarak öğretmenlerin motivasyonlarını yüksek düzeyde olumlu algılamaları, öğretmenlerin kendi motivasyon düzeylerinin yeterliliğini sağlama noktasında, ilgili yönetici davranışlarını cinsiyet değişkenine göre yeterli düzeyde algıladıkları şeklinde açıklanabilir.

Öğretmenlerin motivasyon düzeylerine ilişkin alg1larının branş değişkenine göre dağılımı Tablo 6’da sunulmuştur. 
Ortaokullarda Görev Yapan Öğretmenlerin Öğretmen Motivasyonuna İlişkin Algı ve Görüşleri

Tablo 5. Ortaokullarda Görev Yapan Branş Öğretmenlerinin Motivasyon Düzeyinin Cinsiyet Değişkenine Göre Dağılımı

\begin{tabular}{|c|c|c|c|c|c|c|c|}
\hline Motivasyon & Cinsiyet & $\mathbf{N}$ & $\overline{\bar{X}}$ & $\mathbf{S}$ & sd & t & p \\
\hline Yöneticiyle Çalışma & $\begin{array}{l}\text { Erkek } \\
\text { Bayan }\end{array}$ & $\begin{array}{l}106 \\
105\end{array}$ & $\begin{array}{l}4,41 \\
4,38\end{array}$ & $\begin{array}{l}, 54 \\
, 57\end{array}$ & 209 & $-0,427$ & 0,670 \\
\hline Yönetici Saygısı & $\begin{array}{l}\text { Erkek } \\
\text { Bayan }\end{array}$ & $\begin{array}{l}106 \\
105\end{array}$ & $\begin{array}{l}4,44 \\
4,49\end{array}$ & $\begin{array}{l}, 54 \\
, 47\end{array}$ & 209 & 0,577 & 0,565 \\
\hline $\begin{array}{l}\text { Yönetici-Bireysel İhtiyaç } \\
\text { İlişkisi }\end{array}$ & $\begin{array}{l}\text { Erkek } \\
\text { Bayan }\end{array}$ & $\begin{array}{l}106 \\
105\end{array}$ & $\begin{array}{l}4,09 \\
3,96\end{array}$ & $\begin{array}{l}, 70 \\
, 70\end{array}$ & 209 & $-1,324$ & 0,187 \\
\hline $\begin{array}{l}\text { Yönetici Tutum ve } \\
\text { Davranışları }\end{array}$ & $\begin{array}{l}\text { Erkek } \\
\text { Bayan }\end{array}$ & $\begin{array}{l}106 \\
105\end{array}$ & $\begin{array}{l}4,39 \\
4,40\end{array}$ & $\begin{array}{l}54 \\
, 54\end{array}$ & 209 & 0,018 & 0,985 \\
\hline
\end{tabular}

Tablo 6. Ortaokullarda Görev Yapan Branş Öğretmenlerinin Motivasyon Düzeylerinin Branş Değişkenine Göre Dağılımı

\begin{tabular}{|c|c|c|c|c|c|c|c|}
\hline Motivasyon & Branş & $\mathbf{N}$ & $\bar{X}$ & $\mathbf{S}$ & sd & $\mathbf{F}$ & $\mathbf{p}$ \\
\hline \multirow{6}{*}{$\begin{array}{l}\text { Yönetici ile } \\
\text { Çalışma }\end{array}$} & Türkçe & 57 & 4,43 &, 51 & \multirow{6}{*}{$\begin{array}{l}4 \\
206 \\
210\end{array}$} & \multirow[t]{6}{*}{1,240} & \multirow[t]{6}{*}{0,294} \\
\hline & Matematik & 45 & 4,30 &, 56 & & & \\
\hline & $\begin{array}{l}\text { Fen ve } \\
\text { Teknoloji }\end{array}$ & 39 & 4,41 & ,61 & & & \\
\hline & Sosyal Bilgiler & 30 & 4,27 & ,61 & & & \\
\hline & İngilizce & 40 & 4,51 &, 50 & & & \\
\hline & Toplam & 211 & 4,39 &, 56 & & & \\
\hline Yönetici & Türkçe & 57 & 4,45 &, 53 & 4 & 2,100 & 0,082 \\
\hline \multirow[t]{6}{*}{ Sayg1sı } & Matematik & 45 & 4,36 &, 51 & \multirow{6}{*}{$\begin{array}{l}206 \\
210\end{array}$} & & \\
\hline & Fen ve & 39 & 4,56 &, 46 & & & \\
\hline & Teknoloji & & & & & & \\
\hline & Sosyal Bilgiler & 30 & 4,31 &, 58 & & & \\
\hline & İngilizce & 40 & 4,59 &, 42 & & & \\
\hline & Toplam & 211 & 4,46 &, 51 & & & \\
\hline \multirow{6}{*}{$\begin{array}{l}\text { Yönetici- } \\
\text { Bireysel İhtiyaç } \\
\text { İlişkisi }\end{array}$} & Türkçe & 57 & 3,98 & ,76 & \multirow{6}{*}{$\begin{array}{c}4 \\
206 \\
210\end{array}$} & 0,480 & 0,751 \\
\hline & Matematik & 45 & 3,99 &, 59 & & & \\
\hline & $\begin{array}{l}\text { Fen ve } \\
\text { Teknoloji }\end{array}$ & 39 & 4,10 & ,68 & & & \\
\hline & Sosyal Bilgiler & 30 & 3,93 &, 80 & & & \\
\hline & İngilizce & 40 & 4,11 &, 69 & & & \\
\hline & Toplam & 211 & 4,02 &, 70 & & & \\
\hline \multirow{7}{*}{$\begin{array}{l}\text { Yönetici Tutum } \\
\text { ve Davranışları }\end{array}$} & Türkçe & 57 & 4,46 & ,49 & \multirow{7}{*}{$\begin{array}{c}4 \\
206 \\
210\end{array}$} & \multirow[t]{6}{*}{2,400} & \multirow[t]{6}{*}{0,051} \\
\hline & Matematik & 45 & 4,24 &, 58 & & & \\
\hline & Fen ve & 39 & 4,41 &, 58 & & & \\
\hline & Teknoloji & & & & & & \\
\hline & Sosyal Bilgiler & 30 & 4,27 &, 57 & & & \\
\hline & İngilizce & 40 & 4,55 & ,47 & & & \\
\hline & Toplam & 211 & 4,39 & ,54 & & & \\
\hline
\end{tabular}

Tablo 6’ya göre öğretmenlerin yöneticiyle çalışma, yönetici saygıs1, yönetici-bireysel ihtiyaç ilişkisi ve yönetici tutum ve davranışları boyutlarına ilişkin motivasyonları branşlarına göre anlamlı bir farklılık göstermemektedir. Aritmetik ortalama değerlerinin $(\bar{X}=3,93$ ile $\bar{X}=4,59)$ aralığında değişmesi ve yöne- tici kaynaklı nedenlere bağlı olarak öğretmenlerin motivasyonlarını yüksek düzeyde olumlu algılamaları, öğretmenlerin kendi motivasyon düzeylerinin yeterliliğini sağlama noktasında, ilgili yönetici davranışlarını branş değişkenine göre yeterli düzeyde algıladıkları şeklinde açıklanabilir. 


\section{Nitel Araştırma Yönteminden Elde Edilen Bulgular}

Araștırmanın nitel bölümünde öğretmenlerin görüşlerine başvurulmuştur. Bu kapsam da oluşturulan sorulardan elde edilen görüșler doğrultusunda a- Yöneticilerin, öğretmenlere ve yaptıkları çalıșmalara saygı gösterip göstermemesinin öğretmenlerin motivasyon düzeyine etkisine ilişkin öğretmen görüşleri b- Yöneticilerin, öğretmenlerin bireysel ihtiyaçlarına karşı duyarlı olup olmamasının, öğretmenlerin motivasyon düzeyine etkisine ilişkin öğretmen görüşleri c- Yöneticilerin, yönetime ilişkin tutum ve davranışlarının öğretmenlerin motivasyon düzeyine etkisine ilişkin öğretmen görüşleri olmak üzere 3 tema oluşturulmuş ve konu bu 3 tema altında incelenmiștir.

\section{Yöneticilerin, öğretmenlere ve yaptıkları çalışmalara saygı gösterip göstermemesinin öğretmenlerin moti- vasyon düzeyine etkisine ilişkin öğretmen görüsşleri:}

Katılımcıların çoğunluğu (K2 K3 K4 K8 K9 K15) okul yöneticilerinin kendilerine saygı duyduklarını ancak yaptıkları çalışmalara yeterince değer verip sayg1 duymadıklarını bu durumun ise motivasyonlarını olumsuz yönde etkilediğini ifade ederken K1 K5 K6 K11 K14 rumuzlu katılımcılar yöneticilerin hem kendilerine hem de yaptıkları çalışmalara saygı duyduklarını ve bu anlamda desteklendiklerini belirtmişlerdir. K7, K10, K12, K13 rumuzlu katılımcilar ise ne kendilerine ne de çalışmalarına değer verilmediğini bu nedenle motive olmak bir yana meslekten soğuduklarını ifade etmişlerdir.

Kişisel anlamda kendilerine saygı duyulduğunu ifade eden K2 K3 K4 K8 K9 K15 rumuzlu katılımcilar, okulun gelişimi adına yaptıkları toplantı, seminer, tören v.b sosyal ve kültürel çalışmalar sonucunda mesleki anlamda takdir edilmediklerini, yapacakları çalıșmalara yöneticilerin karar verdiklerini, kendi düşünce ve fikirlerine değer verilmediğini, yöneticilerin hep "ben bilirim" havasında olduklarını bu durumun ise çalışma isteklerini azalttığını ifade etmişlerdir. Bu konuda $K 8$ rumuzlu katılımci "tamam okulda demokratik bir ortam sağlanmış, ama iş eyleme dönüştüğünde yöneticiler burunlarından kıl aldırmıyorlar. Her şeyi kendilerine yontuyorlar, ne yapsak yaranamiyoruz. Hata yaptığımızda yermesini biliyorlar ama iyi bir çalışma yaptı̆̆ımızda takdir edilmiyoruz. Yani kişisel bir saygisizlik yok ama bunun yaninda mesleki bir tatminsizlik var. Açıkçası motivasyonum hızla azalıyor" K2 rumuzlu katılımcı ise yaşadığı bir olayı anlatırken "bir gün okul müdürüm beni yanına çă̆ırdı. Okul ga- zetesi çıkarılacakmış. Bana yapacakları bu çalışmanın olumlu sonuçlarını büyük bir istekle anlattı. Ben de heyecanlandım, yardım edebileceğimi söyledim. Uzun bir çalışma sürecinden sonra gazeteyi çıkardık. Çok ses getirdi. Bende yaptığımız çalş̧madan dolayı bir teşekkür bir takdir bekledim. Ama olmadı verdiğim emeğe gereken saygı gösterilmedi. Artık okul için hiçbir şey yapmak istemiyorum, bütün motivasyonumu aldılar" söyleminde bulunmuştur.

Yöneticilerinin hem kişisel saygı anlamda hem de yaptıkları çalışmaların takdir edilmesi noktasında son derece duyarlı olduğunu ifade eden K1 K5 K6 K11 K14 rumuzlu katılımcilar bulundukları okul ortamını daha çok güzelleştirmek adına yöneticileri ile birlikte ortak çalışmalar yaptıklarını belirtmişlerdir. Bu konuda K5 rumuzlu katılımc1 "yöneticilerimiz çok duyarlıdir, bize her zaman güven telkin ediyorlar ve gerekli saygiyn gösteriyorlar. Bu nedenle okulda her arkadaşım bir iş yapılacağı zaman gönüllü olur. Çünkü biliriz ki yapacağımız çalışmalara değer veriliyor ve okulun gelişim düzeyi hızla artıyor. Ben bunu takım ruhuna bağlyorum. Okul yöneticilerimizde bizim gibi takımin birer parçası ve etkin bir elemanı" K11 rumuzlu katılımcı ise "23 Nisan programın bu yıl ben organize ettim. Yoğun ve eğlenceli birkaç ay geçirdik. Program planlandiğı gibi başarll bir şekilde sona erdi. Okul müdürümüz programa destek veren tüm öğretmenlerimizi ayrı ayrı kutladı. Benim için ise küçük bir plaket yaptırmıştı. Çok mutlu oldum. Motivasyonum ve mesleğime bağhliğım tavan yapt $\imath$ " söyleminde bulunmuştur.

Bu konuda en karamsar tabloyu K7, K10, K12, K13 rumuzlu katılımcılar çizmiştir. Söz konusu katılımcılara göre okul yöneticileri kendilerini öğretmenlerden soyutlamışlar ve okulu bürokratik bir mekanizmaya dönüştürmüşlerdir. Bu durumu K12 rumuzlu katılımcı "ne saygısı gölge etmesinler başka ihsan istemem. Çoğu zaman yöneticileri görmem bile. Bir gün öğretmenler odasına gelip bir güler yüz göstermemişlerdir. Açıkçası okulda işim bitti mi bir dakika durmam, onların yüzünü görmek istemem. Resmi olarak istenen işleri de çalakalem yapar veririm. Motivasyonu geçtim meslekten soğudum" K13 rumuzlu katılımcı ise "yaşadığımız sıkıntı hep yönetici seçme sisteminden kaynaklaniyor. Test yöntemiyle ezberi güçlü olan iyi not alyor. Ama hiç kimse bu adamda yöneticilik becerileri var mı?, insan ilişkileri nast? diye sormuyor. Sonra yönetici olunca ne insana saygı duyuyorlar ne de emeğinize" söyleminde bulunmuştur. Tema içerisinde katılımcıların görüşlerinin dağılımı tablo 7'de sunulmuştur: 
Tablo 7. Öğretmenlere ve Yaptıkları Çalışmalara Yöneticilerin Saygı Gösterip Göstermemelerinin Öğretmen Motivasyonu Üzerine Etkisinin Dağılımı

\begin{tabular}{|c|c|c|c|c|}
\hline Öğretmenlerin; & Yöneticiler; & Katılımcılar & $\mathbf{f}$ & $\%$ \\
\hline $\begin{array}{l}\text { Motivasyonu } \\
\text { olumsuz etkileniyor }\end{array}$ & $\begin{array}{l}\text { Şahsıma saygılı ama yaptığım işe saygılı değil } \\
\text { Ne şahsıma ne de yaptığım işe saygılı değil }\end{array}$ & $\begin{array}{l}K 2 \quad K 3 \quad K 4 \quad K 7 \quad K 8 \quad K 9 \\
K 10 K 12 \text { K13 K15 }\end{array}$ & 10 & 66,6 \\
\hline $\begin{array}{l}\text { Motivasyonu olumlu } \\
\text { etkileniyor }\end{array}$ & Hem şahsıma hem de yaptığım işe saygılı & K1 K5 K6 K11 K14 & 5 & 33,3 \\
\hline
\end{tabular}

Tablo 7’ye göre katılımcıların çoğunluğu $(\% 66,6)$ kendilerine ve yaptıkları çalıșmalara saygı duyulması noktasında yöneticilerin motivasyonlarını olumsuz yönde etkilediğini ifade etmektedir. Bu sonuç nicel bulgularda "yönetici saygısı" boyutunda ortaya çıkan olumlu motivasyon algısı ile örtüşmemektedir. Temada öğretmenlerin cinsiyet ve branş dağılımlarına ilişkin olarak önemli bir farklılık oluşmaması ise nicel bulgularla benzerlik göstermektedir.

Yöneticilerin, öğretmenlerin bireysel ihtiyaçlarına karşı duyarlı olup olmamasının, öğretmenlerin motivasyon düzeyine etkisine ilişkin öğretmen görüşleri:

Katılımciların çoğunluğu (K2 K3 K5 K7 K10 K11 K13 K15) bireysel ilgi ve ihtiyaçlarının karşılanması noktasında yöneticilerin duyarlı olmadığını bu durumun ise çalışma isteklerini azalttığını ifade ederken $K 4 \mathrm{~K} 8$ K9 K12 rumuzlu katılımcılar yöneticilerin zaman zaman bu konuda duyarlı olduklarını ancak kesin tavırlarının ne olduğunu kestiremediklerini, K1 K6 K14 rumuzlu katılımcilar ise yöneticilerin bireysel ihtiyaçlarını karşılama da her türlü yardımı yaptıklarını belirtmiştir.

Bireysel ihtiyaçların karșılanması noktasında yöneticilerin konforlarına düşkün olduğunu ifade eden K2 K3 K5 K7 K10 K11 K13 K15 rumuzlu katılımc1lar, yöneticilerin kendi fiziksel ihtiyaçları için her türlü imkanı seferber ettiklerini iş kendi isteklerine gelince burun kıvırdıklarını işi yokuşa sürdüklerini belirtmișlerdir. Bu konuda $K 7$ rumuzlu katılımcı "o gün kızım rahatsılandı. Seminer dönemi idi. Okulda boş boș oturuyorduk. Okul müdürünün yanına gittim. Durumu izah ettim. Hocam bugün biraz erken çıkayım $\mathrm{m}$ hem burada da yapacak bir ișimiz yok dedim. Ne dese beğenirsiniz? Sizin çocuğunuz erken çımanız için mazeret olamaz. Şok geçirdim. Benim çocuğumun sağllğı mazeret olmaz sa ya ne mazeret olacaktı ki? O dakikadan sonra ne okula ne müdüre saygim sevgim kalmadi. Okula ruh gibi gittim ruh gibi geldim" K13 rumuzlu katılımc1 "bel fitı̆̆ı rahatsızlığım vardı. Ara sira dinlenmem gerekiyordu ama her sandalyede oturamiyordum. Okul müdürümüzden sınıfım için daha rahat bir sandalye rica ettim. Olmaz hocam, bütçemiz ne durumda sen biliyor musun? Ay sonunu zor getiriyoruz dedi. Bunları söylerken rahat ve lüks koltuğuna biraz daha gömüldü. Bende sık sık rapor aldım. Doğru değil ama ne yapayım. Elimden başka bir şey gelmiyor" söyleminde bulunmuştur.

Okul yöneticilerinin bireysel ihtiyaçları konusunda zaman zaman duyarlı olduklarını belirten $K 4 \mathrm{~K} 8$ K9 K12 rumuzlu katılımcılar yöneticilerin bu konuda gösterdiği çelişkili davranışları anlamakta güçlük çektiklerini bu durumun motivasyonlarını azalttığını ifade etmişlerdir. Bu konuda K4 rumuzlu katılımc1 "Hafta içi neredeyse tüm gün okulda oluyoruz. Dışarıda yapmamız gereken ufak tefek işler oluyor. Geçen hafta boş dersim vardı izin istedim, olmaz okulda bulunman gerekir dedi. Bu hafta istedim hadi işini gör de gel dedi. Bizim müdürün galiba bir eşref saati var. Bir yaptı̆̆ bir yaptığın tutmuyor. Bu adamı sevsem mi sevmesem mi karar veremedim. Bu durum çalıșmalarımı da etkiliyor tabi ki" K9 rumuzlu katılımcı ise "ders programları yapılırken özellikle Cuma günümün boşaltılmasını, o gün oğlumun hastanede kontrolleri olduğunu söyledim. Buna rağmen hiçbir günüm boşaltılmadı. Diğer arkadaşların programlarına baktığımda bazılarının boş günleri olduğunu gördüm. İtiraz ettim. Etmez olaydım. Şöyle oldu da böyle oldu da programı yapmak için çok uğraştık, sizin gününüzü boşaltamadik. Tekrar üzerinde oynama yapamayız, dediler. Tüm çalş̧ma şevkim kırıldı. Benim beklentilerimi karşılamayan bir okula ben ne verebilirim ki? söyleminde bulunmuştur.

Bireysel beklentilerinin ve kişisel ihtiyaçlarının karşılanması konusunda okul yöneticilerini yeterli bulan K1 K6 K14 rumuzlu katılıcılar, okul yöneticilerinin insan ilişkileri konusunda çok başarılı olduklarını kendilerini anlama noktasında empati yapabildik- 
lerini ifade etmișlerdir. Bu konuda $K 1$ rumuzlu kat1lımc1 "uzaktan bir akrabam vefat etmiști. Okuldan izin aldım. Okul müdürüm anlayışla karşıladı. Cenazeye katıldım akșam eve döndüm. Okul müdürüm telefonla arayarak bir ihtiyacım olup olmadiğını sordu. Çok sevindim. Adam gibi adam dedim içimden. Bu örnekte olduğu gibi okul müdürümüz bizim bireysel sorunlartmiza ve beklentilerimize her zaman cevap vermeye çalışıyor. Bizde okul için daha çok gayret gösteriyoruz. Bazen hafta sonu bile gelip okul işlerine yardım ediyoruz" söyleminde bulunmuştur. Tema içerisinde katılımc1ların görüşlerinin dağılımı tablo 8'de sunulmuştur:

\begin{tabular}{|c|c|c|c|c|}
\hline Öğretmenlerin; & Yöneticiler; & Katılımeılar & $\mathbf{f}$ & 学, \\
\hline $\begin{array}{l}\text { Motivasyonu olumsuz } \\
\text { etkileniyor }\end{array}$ & $\begin{array}{l}\text { Bireysel ihtiyaçlarıma karşı duyarsızdır } \\
\text { Bazen ihtiyaçlarıma karşı duyarlıdır }\end{array}$ & $\begin{array}{l}\text { K2 K3 K4 K5 K7 K8 K9 K10 } \\
\text { K11 K12 K13 K15 }\end{array}$ & 12 & 8 \\
\hline $\begin{array}{l}\text { Motivasyonu olumlu } \\
\text { etkileniyor }\end{array}$ & Bireysel ihtiyaçlarıma karşı duyarlıdır & K1 K6 K14 & 3 & $\overline{2}$ \\
\hline
\end{tabular}

Tablo 8'e göre katılımcıların çoğunluğu (\% 80) bireysel ihtiyaçlarının karșılanması noktasında yöneticilerin motivasyonlarını olumsuz yönde etkilediğini ifade etmektedir. Bu sonuç nicel bulgularda "yönetici-bireysel ihtiyaç ilişkisi” boyutunda ortaya çıkan olumlu motivasyon algisı ile örtüşmemektedir.

Tablo 8 cinsiyet değişkenine göre değerlendirildiğinde motivasyonu olumsuz etkilenen öğretmenlerin dağılımı (8 kadın; 4 erkek); motivasyonu olumlu etkilenen öğretmenlerin dağılımı (3 erkek) şeklinde ortaya çıkmıştır. Motivasyonu olumsuz etkilenen öğretmenlerin cinsiyet dağılımında daha çok kadın öğretmenlerin yöneticilerin bu tutumundan etkilendiği görülmektedir. Bu durum ise yöneticilerin çoğunlukla erkek olmasına bağlı olarak kadın öğretmenlerin erkek yöneticilerle bireysel ihtiyaçları kapsamında rahat bir şekilde iletişim kuramadıkları şeklinde açıklanabilir. Nicel bulgularda cinsiyete ilişkin bir farklılığın oluşmaması nitel bulgularla çelişmektedir. Ancak bu temada branş dağılımına ilişkin önemli bir farklılık oluşmaması nicel bulgularla benzerlik göstermektedir.

Yöneticilerin, yönetime ilişkin tutum ve davranışlarının öğretmenlerin motivasyon düzeyine etkisine ilişkin öğretmen görüşleri:

Katılımcıların çoğunluğu (K2 K3 K4 K6 K7 K8) yöneticilerin yönetim anlayışlarında duruma göre farklılıklar yaşandığını, yöneticilerin zaman zaman demoktratik zaman zaman otokratik olabildiklerini bu tutarsızlık nedeniyle motivasyonlarında azalma olduğunu, K1 K5 K9 K12 K15 rumuzlu katılımcilar yöneticilerinin demokrat olduğunu ve okullarında ça- lışma anlamında rahat bir ortam bulunduğunu, K10 K11 K13 K14 rumuzlu katılımclar ise yöneticilerinin daha çok otokratik tutum sergilediğini, bu nedenle gönüllü olarak fazladan iş yapmaktan kaçındıklarını belirtmiştir.

Yönetim anlayışının tutarsızlığından yakınan K2 K3 K4 K6 K7 K8 rumuzlu katılımcilar, okulda yapilan faaliyetlerde bir adım sonrasını planlarken ve uygulama sürecine geçerken sürekli tereddüt içerisinde olduklarını, yöneticilerin vereceği tepkileri kestiremedikleri için inisiyatif ve sorumluluk almaktan kaçındıklarını, bu durumun ise yapılan işlerde verimsizliğe neden olduğunu ifade etmişlerdir. Bu konuda K8 rumuzlu katılımc1 "müdürümün vereceği tepkileri kestirememek kadar yorucu bir şey yok. Enerjimi yaptığım işe değil daha çok müdürüm acaba ne der endişesine yönlendirdiğim için ne yaptığım işten zevk alabiliyorum ne de yaptığım iş istediğim gibi oluyor" K3 rumuzlu katılımc1 "ben her zaman demokratik özgürlükçü bir anlayıştan yanayım. Bu ifadeleri okul yöneticileri de söylüyor ama iş yapmaya gelince demokrasinin de'si bile kalmiyor. Hemen otokratik bir kimliğe bürünüp istediklerini yapıyorlar" K6 rumuzlu katılımc1 ise yaşadığı bir olayı anlatırken "kurul toplantısında kutlanacak haftaların dağılımı yapılıyordu. Önce gayet demokratik bir anlayışla ögretmenlere hangi haftaları istedikleri soruldu. Bazı arkadaşlar paylaşım konusunda sorun yaşadılar. Müdürümüz hemen müdahale etti ve tüm otoriter tavrıyla anlaşıldı arkadaşlar ben dağılımı yapıp size tebliğ ederim dedi. Tabi şaşırmadık her zamanki tutarsizlik işte. Sonuç olarak demokratik tutum, ben yaptım oldu, şekline dönüşüverdi. Bu durum çalışma şevkimizi kırlyor" söyleminde bulunmuştur. 
Demokratik ve eşitlikçi bir anlayışla yönetildiklerini dile getiren K1 K5 K9 K12 K15 rumuzlu katılımc1lar, bu yönetim tarzı sayesinde yöneticilerin herkese eşit mesafede durabildiklerini, karar alırken mutlaka öğretmenlerin görüşlerine başvurduklarını ifade etmişlerdir. Bu konuda K15 rumuzlu katılımcı "okul müdürleri ile ilgili bazı olumsuz duyumlarım vard. Ancak şu an çalıştı̆̆ım okul müdürümün demokratik tavrı tüm olumsuz algılarımı değiştirdi. Okulumuza tam bir demokrasi havası hakim. Her şey çok şeffaf şekilde gerçekleşiyor. Bu ortamda kendime güvenim artt. Okulumu ve işimi seviyorum" K5 rumuzlu katılımc1 yaşadığı bir olayı anlatırken "öğrencilerimin okula aidiyet duygularını geliştirmek için formalarının üzerine bir okul arması yapmak istiyordum. Bu konuyu müdür beyle görüştüm. Okul armasının bazı öğrencilerde olmasının bazılarında olmamasının sakıncalı olacağını bu nedenle tüm okulda böyle bir uygulama yapılabileceğini söyledi. Bu konuda karar alırken tüm öğretmenlere, velilere ve öğrencilere sormamız gerektiğini belirtti. Öyle de yaptı. Artık okulumuzun bir arması var" söyleminde bulunmuştur.

Yöneticilerinin otokratik yaklaşımlarından dolayı okula karşı bağlılık geliştiremediklerini ve yaptıkları işe motive olamadıklarını ifade eden $\mathrm{K} 10 \mathrm{~K} 11 \mathrm{~K} 13$ K14 rumuzlu katılımcilar öğretmenler üzerindeki baskının öğrencilerde başarısızlığa neden olduğunu belirtmiştir. Bu konuda K14 rumuzlu katılımcı "otokratik uygulamalardan dolayı okulumuzda öğretmen arkadaşlarımın mutsuz olduğunu görüyorum. Mutsuz insanlarında verimli olamayacağ bir gerçektir. Dolayısıyla okul yöneticilerinin bu tavrı aslinda okul başarısızlğ̆ına, okul başarısızlığı da okul yöneticisinin başarısizlı̆̆ına neden oluyor. Kendi ayaklarına kurşun sıkıyorlar aslında" K13 rumuzlu katılımcı yaşadığı bir olayı anlatırken "okulun en büyük koridorunda nöbetçi idim. Bir taraftan diğer tarafa gitmek bile 3-4 dakikamı alıyordu. Koridorun diğer ucunda öğrencilerin kavga ettiğini gördüm. Hemen oraya yöneldim. Okul müdürümde tesadüfen olaya daha yakın bir yerde imiş. Benden önce o müdahale etti. Sonra koridorda beni de azarladı. Çok utandım. Bu kadar sert çıkmaya gerek yoktu aslinda. O günden sonra okuldan ve öğrencilerimden soğudum, çalışma isteğim kalmadı" söyleminde bulunmuştur. Tema içerisinde katılımcıların görüşlerinin dağıllımı tablo 9'da sunulmuştur:

Tablo 9'a göre katılımcıların çoğunluğu $(\% 66,6)$ yöneticilerin yönetime ilişkin tutum ve davranışlarının motivasyonlarını olumsuz yönde etkilediğini ifade etmektedir. Bu sonuç nicel bulgularda "Yönetici Tutum Davranışları" boyutunda ortaya çıkan olumlu motivasyon algısı ile örtüşmemektedir.

Tablo 9. Yöneticilerin Yönetime Ilişskin Tutum ve Davranışlarının Öğretmen Motivasyonu Üzerine Etkisinin Dağılımı

\begin{tabular}{|c|c|c|c|c|}
\hline Öğretmenlerin; & Yöneticiler; & Katılımcilar & $\mathbf{f}$ & $\%$ \\
\hline $\begin{array}{l}\text { Motivasyonu olumsuz } \\
\text { etkileniyor }\end{array}$ & $\begin{array}{l}\text { Bazen demokratik bazen otokratiktir } \\
\text { Daha çok otokratiktir }\end{array}$ & $\begin{array}{l}\text { K2 K3 K4 K6 K7 K8 K10 K11 } \\
\text { K13 K14 }\end{array}$ & 10 & 66,6 \\
\hline $\begin{array}{ll}\begin{array}{l}\text { Motivasyonu } \\
\text { etkileniyor }\end{array} & \end{array}$ & Her zaman demokratiktir & K1 K5 K9 K12 K15 & 5 & 33,3 \\
\hline
\end{tabular}

Tablo 9 branş değişkenine göre değerlendirildiğinde motivasyonu olumsuz etkilenen öğretmenlerin dağ1lımı (3 İngilizce; 3 Matematik; 3 Fen Bilgisi; 1 Sosyal Bilgiler); motivasyonu olumlu etkilenen öğretmenlerin dağılımı (3 Türkçe; 2 Sosyal Bilgiler) şeklinde ortaya çıkmıştır. Branş dağılımında motivasyonu olumlu etkilenen Türkçe ve Sosyal bilgiler öğretmenlerinin yönetici tutumlarını demokratik olarak ifade etmeleri, bu branşta görev yapan öğretmenlerin okulda yapılan sosyal ve kültürel faaliyetlerde etkin olmalarına, bu bağlamda yöneticilerle diğer branşlara göre daha yakın ilişkiler kurmalarına bağlanabilir. Nicel bulgularda branşa ilişkin bir farklılığın oluşmaması nitel bulgularla çelişmektedir. Ancak bu temada cinsiyet dağılımına ilişkin önemli bir farklılık oluşmaması nicel bulgularla benzerlik göstermektedir.

\section{Tartışma ve Sonuç}

Araştırmada, motivasyon düzeyi ve alt boyutları, seçeneklere göre kodlanan puan aralı̆̆ı (SKPA) dikkate alınarak değerlendirildiğinde, örneklem grubundaki öğretmenlerin algılarına göre yöneticiyle çalışma $(\bar{X}$ $=4,39)$, yönetici saygısı $(\bar{X}=4,46)$, yönetici tutum ve davranışları $(\overline{\mathrm{X}}=4,41)$ boyutlarının "tamamen katılıyorum" düzeyinde; yönetici-bireysel ihtiyaç ilişkisi 
boyutunda ( $\overline{\mathrm{X}}=4,01)$ "kat1liyorum" düzeyinde olduğu görülmektedir. Motivasyon düzeyi toplamda ise $(\overline{\mathrm{X}}=4,31)$ "tamamen katıliyorum" şeklinde algılanmıștır. Öğretmenlerin tüm boyutlarda yönetici kaynaklı nedenlere bağlı olarak motivasyon düzeylerini "tamamen katıllyorum" ve "katılıyorum" düzeyinde olumlu algılamaları öğretmenlerin kendi motivasyon düzeylerinin yeterliliğini sağlama noktasında, ilgili yönetici davranışlarını yeterli düzeyde algıladıkları şeklinde açıklanabilir. Alan yazında benzer araştırma bulgularına rastlanmıştır (Aslan 2011; Güzel, 2011; Özan vd. 2012; Arık1l ve Yorganc1, 2012; Ünal, 2000; Özdoğru ve Aydın, 2012). Ancak Justine’ in (2011) Nijerya'da orta dereceli okullarda yaptığ1 araştırmada öğretmenlerin motivasyon düzeyleri ile performansları arasında zayıf bir ilişki olduğuna yönelik bulgusu, alan yazında ortaya çıkan öğretmen motivasyonunun olumlu etkilerine yönelik genel algı ile çelişmektedir. Ayrıca alan yazında öğretmenlerin motivasyon düzeyi yüksek düzeyde algılanmasına rağmen Güzel'in (2011) okulların büyük bölümünde fizikî imkânların yetersizliği, düşük öğretmen ücretleri, sosyal imkânsızlıklar ve yönetimsel sorunlar gibi nedenlerden dolayı Türkiye’de öğretmen motivasyonunda önemli sorunların olduğunu belirtilmesi düşündürücüdür.

Öğretmenlerin yöneticiyle çalışma, yönetici saygısı, yönetici-bireysel ihtiyaç ilişkisi ve yönetici tutum ve davranışları boyutlarına ilişkin motivasyonları cinsiyetlerine göre anlamlı bir farklılık göstermemektedir. Aritmetik ortalama değerlerinin $(\overline{\mathrm{X}}=3,96$ ile $\overline{\mathrm{X}}$ $=4,49$ ) aralığında değişmesi ve yönetici kaynaklı nedenlere bağlı olarak öğretmenlerin motivasyonlarını yüksek düzeyde olumlu algılamaları, öğretmenlerin kendi motivasyon düzeylerinin yeterliliğini sağlama noktasında, ilgili yönetici davranışlarını cinsiyet değişkenine göre yeterli düzeyde algıladıkları şeklinde açılanabilir. İbak (2010), Yılmaz (2009), Yıldırım (2009), Delipoyraz (2009) ve Ebcim (2012) yaptıkları çalışmalar sonucunda elde ettikleri bulgular da bu sonucu destekler niteliktedir. Ancak Köprülü’nün (2011) ve Özan, Türkoğlu ve Şener'in (2012) çalışmalarında bayan öğretmenlerin motivasyon düzeylerinin erkek öğretmenlerin motivasyon düzeylerine göre anlamlı düzeyde yüksek olduğu sonucuna ulaşması; Bektaşin (2010) çalışmasının sonucunda yönetici-bireysel ihtiyaç ilişkisi boyutunda cinsiyet değişkenine göre anlamlı farklılık olduğunu belirtmesi bu araştırma sonuçları ile çelişmektedir.
Öğretmenlerin yöneticiyle çalışma, yönetici saygısı, yönetici-bireysel ihtiyaç ilişkisi ve yönetici tutum ve davranışları kaynaklı motivasyonları branşlarına göre anlamlı bir farklılık göstermemektedir. Aritmetik ortalama değerlerinin $(\overline{\mathrm{X}}=3,93$ ile $\overline{\mathrm{X}}=4,59)$ aralığında değişmesi ve yönetici kaynaklı nedenlere bağlı olarak öğretmenlerin motivasyonlarını yüksek düzeyde olumlu algılamaları, öğretmenlerin kendi motivasyon düzeylerinin yeterliliğini sağlama noktasında, ilgili yönetici davranışlarını branş değişkenine göre yeterli düzeyde algıladıkları șeklinde açıklanabilir. İbak (2010), Ebcim (2012) ve Çalıș (2012) yaptıkları çalışmalar sonucunda elde ettikleri bulgular da bu sonucu destekler niteliktedir. Ancak Özan, Türkoğlu ve Şener'in (2012) araştırmasında sınıf öğretmenlerinin branş öğretmenlerine göre yöneticilerin motivasyon sağlamaya ilişkin davranışlarını daha olumlu değerlendirdikleri sonucuna ulaşması bu araştırma sonuçları ile çelişmektedir.

Araştırmanın nitel bulgularına göre katılımcıların çoğunluğu $(\%$ 66,6) kendilerine ve yaptıkları çalışmalara saygı duyulması noktasında yöneticilerin motivasyonlarını olumsuz yönde etkilediğini; katılımc1ların çoğunluğu (\% 80) bireysel ihtiyaçlarının karşılanması noktasında yöneticilerin motivasyonlarını olumsuz yönde etkilediğini; katılımcıların çoğunluğu $(\% 66,6)$ yöneticilerin yönetime ilişkin tutum ve davranışlarının motivasyonlarını olumsuz yönde etkilediğini ifade etmektedir. Bu sonuçlar nicel bulgularda "yönetici saygısı", "yönetici-bireysel ihtiyaç ilişkisi" ve "yönetici tutum davranışları" boyutlarında ortaya çıkan öğretmenlerin yönetici kaynaklı olumlu motivasyon algısı ile örtüşmemektedir. Bu durumun nedeni ise nicel çalışmada kullanılan ölçeğin yapılandırılmış kapalı uçlu sorulardan oluşması, ölçeğe cevap veren öğretmenlerin kendilerine verilen, belli sinırlılıkları olan seçenekleri doldurmaları ve asıl düşüncelerini bu cevaplara yansitamamaları olabilir. Nicel sorularda ise öğretmenlerin görüşme sırasında kendilerini daha iyi ifade ettikleri, yaşadıkları olayları ve tecrübeleri anlatma firsatı yakaladıkları söylenebilir. Bu bağlamda Aksoy’un (2005) ilköğretim okulu yöneticilerinin öğretmenler için motivasyonun ne denli önemli olduğunu bildikleri halde öğretmenleri motive etmek için gerekli iletişim becerilerini kullanmadıkları yönündeki tespitleri; Güneş่in (2007) araştırma sonucunda, ilköğretim okullarında görev yapan okul müdürlerinin iletişim ve motivasyon becerilerini yeterince kullanmadıklarını ifade 
etmesi; Neves ve Lens'in (2005) öğretmenlerin, diğer bir çok profesyonel meslek grubundan daha çok mesleki motivasyon eksikliği yaşadığını belirtmesi bu araştırmanın nitel bulgularını destekler niteliktedir. Nitel bulgularda öğretmen motivasyonu konusunda ortaya çıkan memnuniyetsizlik okul yöneticilerinin yeterlilikleri konusunda soru işaretleri oluşturmaktadır. Ünal'a göre (2011) öğretmenler okuldaki temel uygulayıcılar olarak öğrendikleri bilgi ve becerilerini daha kolay uygulayabilecekleri ortamlarda çalışmak, böylece kendilerini gösterme, takdir edilme, kendinin önemli olduğunu ortaya koyma gibi güdülerini doyurma ihtiyacı içindedirler. Bu nedenle okul yöneticileri uygun ortamlar sağlayarak öğretmenlerin motivasyonlarını artırabilmelidir.

Araştırmanın nitel bulguları cinsiyet ve branş değişkenlerine göre incelendiğinde;

Bireysel ihtiyaçların karşılanmasına ilişkin öğretmen görüşlerine yer verilen temada, motivasyonu olumsuz etkilenen öğretmenlerin dağılımı (8 kadın; 4 erkek); motivasyonu olumlu etkilenen öğretmenlerin dağılımı (3 erkek) şeklinde ortaya çıkmıştır. Motivasyonu olumsuz etkilenen öğretmenlerin cinsiyet dağılımında daha çok kadın öğretmenlerin yöneticilerin bu tutumundan etkilendiği görülmektedir. $\mathrm{Bu}$ durum ise yöneticilerin çoğunlukla erkek olmasına bağlı olarak kadın öğretmenlerin erkek yöneticilerle bireysel ihtiyaçları kapsamında rahat bir şekilde iletişim kuramadıkları şeklinde açıklanabilir. Nicel bulgularda cinsiyete ilişkin bir farklılığın oluşmaması nitel bulgularla çelişmektedir. Nicel ve nitel bulgular arasındaki farklılıklar öğretmenlerin nitel görüşme yönteminde kendilerini daha iyi ifade edebildiklerine bağlanabilir. Öğretmenlerin kişisel beklentilerinin karşılanması noktasında Ünal (2011) ilköğretim okulu yöneticilerinin öğretmenleri motive eden örgütsel amaçları gerçekleştirmeye çalışırken öğretmenlerin kişisel beklentilerini de yerine getirmeyi sağlayan bir ortam yaratmasının sistemin başarısı için büyük önem taşıdığını ifade etmiştir. Ayrıca Güneş (2007) okul yöneticilerinin motivasyon konusunda kendilerini yenileyip, geliştirmeleri ve öğretmenlerin beklentilerini dikkate almaları gerektiğini belirtmiştir. Neves ve Lens ise (2005) konuya farklı bir bakış açısı getirerek öğretmenin sıradan bir sıkıntısının bile öğrencilerin öğrenme motivasyonlarını etkileyeceğine bu bağlamda öğretmen motivasyonun, eğitim yöneticileri açısından önemli bir konu olduğuna vurgu yapmıştır.
Yöneticilerin yönetime ilişkin tutum ve davranışlarına ilişkin öğretmen görüşlerine yer verilen temada motivasyonu olumsuz etkilenen öğretmenlerin dağ1lımı (3 İngilizce; 3 Matematik; 3 Fen Bilgisi; 1 Sosyal Bilgiler); motivasyonu olumlu etkilenen öğretmenlerin dağılımı (3 Türkçe; 2 Sosyal Bilgiler) şeklinde ortaya çıkmıştır. Branş dağılımında motivasyonu olumlu etkilenen Türkçe ve Sosyal bilgiler öğretmenlerinin yönetici tutumlarını demokratik olarak ifade etmeleri, bu branşta görev yapan öğretmenlerin okulda yapilan sosyal ve kültürel faaliyetlerde etkin olmalarına, bu bağlamda yöneticilerle diğer branşlara göre daha yakın ilişkiler kurmalarına bağlanabilir. Nicel bulgularda branşa ilişkin bir farklılı̆̆ın oluşmaması nitel bulgularla çelişmektedir. Yöneticilerin yönetime ilişkin tutum ve davranışlarının demokratik olması istenen ve olması gereken durumu yansitmaktadır. Bu doğrultuda Özan vd. (2012) okul yöneticilerinin sergiledikleri demokratik tutum ve davranışların öğretmenlerin motivasyonunu etkilemedeki rolünün olumlu düzeyde olduğuna yönelik bulgusu demokratik yönetici tutumlarını destekler niteliktedir. Öğretmen motivasyonunun arttırılması noktasında Koçak ve Özüdoğru (2012) çalışanları kararlara katılma imkânı sağlayan, dinleyen, destekleyen, güven veren Maçin (2010) iletişim becerileri yüksek olan yöneticilere ihtiyaç duyulmaktadır. Çünkü Çiftçi (2008) okul yöneticileri, öğretmenlerin motivasyonlarını arttırıcı faaliyetlerde bulunduğu ölçüde yönetici-öğretmen ve öğretmen-öğretmen iletişimi gelişecektir.

Bireysel ihtiyaçların karşılanmasına ilişkin öğretmen görüşlerine yer verilen temada branş dağılımına ilişkin önemli bir farklılık oluşmaması; yöneticilerin yönetime ilişkin tutum ve davranışlarına ilişkin öğretmen görüşlerine yer verilen temada cinsiyet dağılımına ilişkin önemli bir farklılık oluşmaması; yönetici saygısına ilişkin öğretmen görüşlerine yer verilen temada öğretmenlerin cinsiyet ve branş dağılımlarına ilişkin olarak önemli bir farklılık oluşmaması ise nicel bulgularla benzerlik göstermektedir.

Araştırma kapsamında:

1. Araştırma da nicel ve nitel bulgular arasında ortaya çıkan farklılıkların nedenlerine yönelik araştırmaların yapılması,

2. Öğretmen motivasyonu konusunda yönetici, öğretmen, öğrenci ve veli görüsslerine dayalı nitel araştırmaların yapılması, 
3. Öğretmen motivasyonun arttırılması amacıyla;

a- Okul yöneticilerinin, öğretmenlerin bireysel ihtiyaçlarının karşılanmasına yönelik tedbirler almaları,

b- Okul yöneticilerinin, öğretmenlerin yaptıkları çalışmalara değer verilmesine yönelik tedbirler almaları,

c- Okul yöneticilerinin, demokratik tutum geliştirme noktasında tedbirler almaları,

d- Milli Eğitim Bakanlığının geniş çaplı politikalar üretmesi önerilebilir.

\section{Kaynakça}

Ahmad, I. (2011). Effect of teacher efficacy beliefs on motivation. Journal of Behavioural Sciences, 21(2), $35-46$.

Aksoy, İ. (2005). İlköğretim okullarında görev yapan öğretmenlerin, okulda değişim yönetiminin gerçekleştirilmesinde, örgütsel iletişimin rolüne ilişkin algıları (Yayımlanmamış yüksek lisans tezi). Gazi Üniversitesi, Eğitim Bilimleri Enstitüsü, Ankara.

Arıkıl, G. \& Yorgancı, B. (2012). Öğretmenlerin, öğretmen adaylarının ve öğrencilerin motivasyonu algilama farklılıkları. X. Ulusal Fen Bilimleri ve Matematik Eğitimi Kongresi, 27-30 Haziran 2012, 1-15. Niğde: Niğde Üniversitesi Rektörlüğü.

Aslan, K. (2001). Eğitimin toplumsal temelleri. Balıkesir Üniversitesi Sosyal Bilimler Dergisi, 5,16-30.

Aydın, A. H. (2011). Yönetim Bilimi. Ankara: Seçkin Yayıncilık.

Aydın, M. (2010). Eğitim Yönetimi (9. Baskı). Ankara: Hatiboğlu Yayıncilık.

Balc1, A. (2010). Sosyal Bilimlerde Araştırma (Yöntem, Teknik ve İlkeler). (8. Baskı). Ankara: Pegem Akademi.

Baygül, B. \& İnam, Ö. (2006). Kurum içi iletişim: çalışanların sağlıklı iş yaşamı beklentilerinin betimlenmesine yönelik bir çalıșma. 2. Ulusal Halkla İlişkiler Sempozyumu, 27-28 Nisan 2006, 92-100. Kocaeli: Kocaeli Üniversitesi Rektörlüğü.
Bektaş, A. (2010). İlköğretim okulları yöneticilerinin sosyal iletişim becerileri ile sınıf öğretmenlerinin motivasyonu arasındaki ilişki (Yayımlanmamıș yüksek lisans tezi). Gazi Üniversitesi Eğitim Bilimleri Enstitüsü, Ankara.

Bilgin, N. (2006). Sosyal Bilimlerde İçerik Analizi. (2. Baskı). Ankara: Siyasal Yayıncilık.

Büyüköztürk, Ş., Çakmak, E.K., Akgün, K.Ş. \& Demirel, F. (2012). Bilimsel Araştırma Yöntemleri. (12. Basım). Ankara: Pegem A Yayıncilık.

Ciani, K., Ferguson, Y., Bergin, D. \& Hilpert, J. (2010). Motivational influences on school-prompted interest. Educational Psychology, 30(4), 377-393.

Çalış, H. (2012). Öğretmen motivasyonunda yönetici yaklaşımlarının incelenmesi (Yayımlanmamış yüksek lisans tezi). Yeditepe Üniversitesi Sosyal Bilimler Enstitüsü, İstanbul.

Çiftçi, Ü. (2008). İlköğretim öğretmenleri arasındaki iletişim sorunları (Yayımlanmamış yüksek lisans tezi). Beykent Üniversitesi Sosyal Bilimler Enstitüsü, İstanbul.

Delipoyraz, M. (2009). Motivasyon unsuru olarak kariyer yönetimi ve resmi ilköğretim okullarında bir uygulama. (Yayımlanmamıș yüksek lisans tezi) Beykent Üniversitesi Sosyal Bilimler Enstitüsü, İstanbul.

Ebcim, P. Ö. (2012). Resmi ilköğretim okullarında çalışan öğretmenlerin motivasyonu ile örgüt sağlı̆̆ algıları arasındaki ilişki (Yayımlanmamış yüksek lisans tezi). Maltepe Üniversitesi Sosyal Bilimler Enstitüsü, İstanbul.

Griffin, D. K. (2010). A Survey of Bahamian and Jamaican teachers' level of motivation and job satisfaction. Journal of Invitational Theory \& Practice, 16, 56-76.

Gündüz, A. (2009). Yönetim sürecinde yöneticilerin sergilediği davranışların çalışanların motivasyonuna etkisi: eğitim kurumlarında bir uygulama. (Yayımlanmamış yüksek lisans tezi). Beykent Üniversitesi Sosyal Bilimler Enstitüsü, İstanbul. 
Güneş, K. (2007). İlköğretim okulu öğretmenlerinin okul müdürlerinin iletişim ve motivasyon becerileri ile ilgili algı ve beklentileri (Yayımlanmamış yüksek lisans tezi). Yeditepe Üniversitesi Sosyal Bilimler Enstitüsü, İstanbul.

Gürgen, H. (1997). Örgütlerde İletişim Kalitesi. İstanbul: Der Yayınları.

Gürsel, M. (1997). Okul Yönetimi. Konya: Mikro Yayınları.

Gürüz, D. \& Yaylac1, G. Ö. (2007). İnsan kaynakları yönetimi: iletişimci gözüyle (3. Baskı). İstanbul: MediaCat Kitapları.

Güzel, H. (2011). Fizik öğretmenlerinin demografik özellikleri ve motivasyon faktörlerinin araştırılmas1. Kuram ve Uygulamada Eğitim Bilimleri, 11(2), 1031-1054.

Harris E. (1992). A principaland and the evolution of a school culture: a case study. Planingand Changing, 1(23), 29-44.

Harzing, A. W. \& Ruysseveldt, J. V. (1995). İnternational Human Resource Management. New Delhi: SAGE Publications London.

İbak, S. (2010). İlköğretim okulu müdürlerinin öğretmenleri güdüleme rollerini gerçekleştirme düzeylerine ilişkin öğretmen görüşlerinin çeşitli değişkenler açısından incelenmesi (Yayımlanmamış yüksek lisans tezi). Yeditepe Üniversitesi Sosyal Bilimler Enstitüsü, İstanbul.

Jesus, S. N. D. \& Abreu, M. V. (1994). Study of teachers' motivation to motivate students by the theory of planned behavior. (Eric No. ED400235).

Justine, N. (2011). Motivational Practices and Teachers' Performance in Jinja Municipality Secondary Schools, Jinja District, Uganda. (Eric No. ED531291).

Karadeniz, B.C. \& Yavuz, C. (2009). Sınıf öğretmenlerinin motivasyonunun iş tatmini üzerine etkisi. Uluslararası Sosyal Araştırmalar Dergisi, 2 (9), 507-509.

Karasar, N. (2011). Bilimsel Araştırma Yöntemleri. Ankara: Nobel Yayıncilık.
Karagöz, M. (2010). İlköğretim okulu yöneticilerinin öğretmenleri motive etme becerileri (Yayımlanmamış yüksek lisans tezi). Beykent Üniversitesi Sosyal Bilimler Enstitüsü, İstanbul.

Kaur, K. \& Kaur, P. (2013). Relationship between self - efficacy and teacher motivation of secondary school teachers of punjab. Indian Streams Research Journal, 3(9), 1-5.

Koçak, R. D. \& Özüdoğru, H. (2012). Yöneticilerin liderlik özelliklerinin çalışanların motivasyonu ve performansı üzerindeki etkileri: kamu ve özel hastanelerinde bir uygulama. Ticaret ve Turizm Eğitim Fakültesi Dergisi, 1, 76-88.

Köprülü, S. T. (2011). İlköğretim okullarındaki öğretmenlerin örgütsel vatandaşlık davranışları ile motivasyonları arasındaki ilişki (Yayımlanmamış yüksek lisans tezi). Maltepe Üniversitesi Sosyal Bilimler Enstitüsü, İstanbul.

Liu, S. \& Onwuegbuzie, A. J. (2011). Teachers' motivation for entering the teaching profession and their job satisfaction: a cross-cultural comparison of China and other countries. Learning Environments Research, 1-20.

Lunenburg, F. C. \& Ornstein, A. C. (1996). Educational administration (Second Edition). California: Wadsworth Publishing Company.

Maçin, E. (2010). Yönetici iletişim becerilerinin çalışan motivasyonu üzerine etkileri (Yayımlanmamış yüksek lisans tezi). Beykent Üniversitesi Sosyal Bilimler Enstitüsü, İstanbul.

Mills, G. E. (2003). Action research a guide for the teacher researcher (2 nd. edition). Pearson Education, Boston.

Morcom, V. \& MacCallum, J. (2009). Motivation in action" in a collaborative primary classroom: developing and sustaining teacher motivation. Australian Journal of Teacher Education, 34(6), 23-40.

Neves de Jesus, S. \& Lens, W. (2005). An integrated model for the study of teacher motivation. Applied Psychology, 54(1), 119-134. 
Ololube, N. P. (2006). Teachers job satisfaction and motivation for school effectiveness: an assessment. Essays In Education. (Eric No. ED496539).

Özan, M. B., Türkoğlu, A. Z. \& Şener, G. (2012). Okul yöneticilerinin sergiledikleri demokratik tutum ve davranışlarının öğretmenlerin motivasyonuna etkisi. Firat Üniversitesi Sosyal Bilimler Dergisi, 20 (1), 275-294.

Özdoğru, M. \& Aydın, B. (2012). İlköğretim okulu öğretmenlerinin karara katılma durumları ve istekleri ile motivasyon düzeyleri arasındaki ilişki. Abant İzzet Baysal Üniversitesi Eğitim Fakültesi Dergisi, 12(2), 357-367.

Özgan, H. \& Aslan, N. (2008). İlköğretim okul müdürlerinin sözlü iletiş̧im biçiminin öğretmenlerin motivasyonuna etkisinin incelenmesi. Gaziantep Üniversitesi Sosyal Bilimler Dergisi, 7 (1), 190-206.

Papi, M. \& Abdollahzadeh, E. (2012). Teacher motivational practice, student motivation, and possible L2 selves: An examination in the Iranian EFL context. Language Learning, 62(2), 571-594.

Sabancı, A. (1994). Eğitim yönetiminde çift yönlü iletişim yönetilenleri is doyumu ve motivasyon bakımindan nasil etkilemektedir? (Yayımlanmamıs Bilim Uzmanlığı Tezi). İnönü Üniversitesi, Malatya, Türkiye.

Sakui, K. \& Cowie, N. (2012). The dark side of motivation: teachers' perspectives on 'unmotivation'. ELT Journal, 66(2), 205-213.

Sergiovanni, T.J. \& Starratt, R.J. (1993). Supervision: A Redefination (5.Bask1). Singapore: McGraw-Hill, Inc.

Sönmez, V. \& Alacapınar, G. F. (2011). Örneklendirilmiş Bilimsel Araştırma Yöntemleri. Ankara: Anı yayıncilık.

Şişman, M. (2003). Öğretmenlik Mesleğine Giriş. Ankara: Pegem A Yayıncilık.

Torbacioğlu, D. (2007). İlköğretim okulu yöneticilerinin iletişim yöntemleri ve güdüleme derecelerine ilişkin öğretmen algıları (Yayımlanmamış yüksek lisans tezi). Yeditepe Üniversitesi Sosyal Bilimler Enstitüsü, İstanbul,
Tuna, M. \& Türk, S.M. (2006). Kamu ve özel sektör matbaa işletmelerinde çalışanların içsel motivasyon düzeylerinin karşılaştırılması, Selçuk Üniversitesi Sosyal Bilimler Enstitüsü Dergisi, 16, 619-632.

Ünal, S. (2000). İlköğretim okulu yöneticilerinin okullarında motivasyonu sağlama etkinlikleri. Pamukkale Üniversitesi Eğitim Fakültesi Dergisi, 1, 84-90.

Wahab, J. A., Hamid, A. H. A., Zainal, S. \& Rafik, M. F. M. (2013). The relationship between headteachers' distributed leadership practices and teachers' motivation in national primary schools. Asian Social Science, 9(16), 161-167.

Vrieling, E., Bastiaens, T. \& Stijnen, S. (2012). Consequences of increased self-regulated learning opportunities on student teachers motivation and use of metacognitive skills. Australian Journal of Teacher Education, 37(8), 102-117.

Yazıcı, H. (2009). Öğretmenlik mesleği, motivasyon kaynakları ve temel tutumlar: kuramsal bir bakış. Kastamonu Eğitim Fakültesi Dergisi, 17 (1), 33-46.

Yazıcıoğlu, Y. \& Erdoğan, S. (2004). SPSS uygulamalı bilimsel araştırma yöntemleri. Ankara: Detay Yayincilik.

Yıldırım, A. \& Şimşek, H. (2011). Sosyal bilimlerde nitel araştırma yöntemleri. (8. Baskı). Ankara: Seçkin Yayıncilık.

Yıldırım, S. (2009). İlköğretim okullarında yöneticilerin sınıf öğretmenlerini güdüleme davranışları ve gerçekleşme düzeylerine ilişkin öğretmen ve yönetici görüşleri. (Yayımlanmamış yüksek lisans tezi). Selçuk Üniversitesi Sosyal Bilimler Enstitüsü, Konya.

Yılmaz, A. \& Ceylan, Ç.B. (2011). İlköğretim okul yöneticilerinin liderlik davranış düzeyleri ile öğretmenlerin iş doyumu ilişkisi. Kuram ve Uygulamada Eğitim Yönetimi, 17 (2), 277-394.

Yılmaz, F. (2009). Eğitim örgütlerinde örgüt kültürünün öğretmenlerin iş motivasyonu üzerindeki etkisi (Yayımlanmamış yüksek lisans tezi). Selçuk Üniversitesi Sosyal Bilimler Enstitüsü, Konya. 